\title{
Complementary Diet of Cathartes burrovianus (Cathartidae) With Fruit Elaeis guineensis (Arecaceae)
}

\author{
José A. Batista-da-Silva ${ }^{1,2}$ \& Antonio E. A. Souza ${ }^{1,2}$ \\ ${ }^{1}$ Secretaria Municipal de Educação e Cultura (SEMEC), Prefeitura Municipal de Itaboraí (RJ), Brazil \\ ${ }^{2}$ Praça Marechal Floriano Peixoto, 18, Centro, Itaboraí, Rio de Janeiro, Brazil \\ Correspondence: José A. Batista-da-Silva, Secretaria Municipal de Educação e Cultura (SEMEC), Prefeitura \\ Municipal de Itaboraí (RJ), Brazil. Tel: 55-21-3638-2563. E-mail: zeize@uol.com.br
}

\author{
Received: August 4, 2014 Accepted: August 31, 2014 Online Published: October 15, 2014 \\ doi:10.5539/jas.v6n11p58 URL: http://dx.doi.org/10.5539/jas.v6n11p58
}

\begin{abstract}
The mangrove swamps of the Guapi-Mirim Environmental Protection Area are rich in animal diversity. Due to its considerable size there is a generous supply of prey for any predator as well as significant food resources for animal scavengers. The vultures, which are carrion or predatory birds are included in the order Cathartiformes (Cathartidae) and the most common species in Brazil are: Cathartes aura (Linnaeus, 1758), Cathartes burrovianus Cassin, 1845; Cathartes melambrotus Wetmore, 1964; Coragyps atratus (Bechstein, 1793) and Sarcoramphus papa (Linnaeus, 1758). In the mangrove swamps of this protected area three species of vultures are commonly seen: $C$. aura, C. burrovianus e C. atratus. These three species basically have a diet of animal carcasses. All the Cathartes burrovianus observations carried out in this study were made in a small part of the mangrove swamps in the Guapi-Mirim APA, located in the district of Itambi, Itaboraí, Rio de Janeiro, Brazil. The observations were made every two weeks for a year and photography was used to record the birds. A total of 78 photographic observations were made of these birds (C. burrovianus) feeding on the fruit of the oil palm Elaeis guineensis Jacq. 1897. As the mangrove swamp has abundant food resources throughout the year, it was concluded that $C$. burrovianus feeds on the fruits of the palm E. guineensis not only as an alternative food in the absence of carcasses, but also a complement to their dietary needs. It is the first record of this feeding behavior. This fact may be related to the higher digestibility of carcasses consumed by these animals.
\end{abstract}

Keywords: Mangroves swamps, oleaginous fruit, vulture

\section{Introduction}

Vultures are raptorial birds that are included in the order Cathartiformes (Cathartidae) and in Brazil the following species are found: Cathartes aura (Linnaeus, 1758), Cathartes burrovianus Cassin, 1845; Cathartes melambrotus Wetmore, 1964; Coragyps atratus (Bechstein, 1793) and Sarcoramphus papa (Linnaeus, 1758). These five species all have relevant ecological importance as they usually feed on decaying carcasses (Wink, 1995).

Of the all species mentioned above, C. melambrotus is the only one that is restricted to primary forest (Houston, 1994). What is most notable in these species is their behavior, habitat and their foraging strategies; however aspects linked to migration or reproduction are rarely described (Olmos et al., 2006).

The species C. burrovianus (Lesser Yellow-headed Vulture) is present throughout South America, except Chile (Ferguson-Lees \& Christie, 2005). They inhabit various different environments, including swampy areas (Brown \& Amadon, 1989; Sick, 2001; Ferguson-Lees \& Christie, 2005) and basically feed on carcasses or prey (Sigrist, 2006; Silveira \& Belmonte, 2005; Almeida et al., 2010).

Mangrove swamps are ecosystems belonging to the Atlantic Forest. The soil is basically muddy, formed by the decomposition of plants and animals. However within this scenario there are a few specimens of the exotic plant Elaeis guineensis Jacq. 1897. The palm is native to Africa and has been naturalized to Latin America and Asia among other regions (Bakoumé et al., 2013). Its fleshy fruits are rich in oil and are greatly appreciated by many birds. The growth of the African oil palm and its fruit production are directly related to the amount of water available (Bakoumé et al., 2013).

The consumption of carcasses in decomposition by vultures is well known all over the world, however the observation of carrion birds of the family Cathartidae feeding on other food resources would represent an 
important behavioral change of this group, as this behavior of $C$. burrovianus has not been reported previously. Therefore the goals of this study are: a) to investigate the use of the fruits from the African oil palm ( $E$. guineensis) by $C$. burrovianus as a complementary source of food in mangrove swamps and b) to observe their behavior during feeding time.

\section{Material and Methods}

All observations were made in the Guapi-Mirim Environmental Protection Area (APA de Guapi-Mirim), which is situated within Guanabara Bay. The protected area spreads through the municipalities of São Gonçalo, Itaboraí, Guapimirim and Magé, and the geographic coordinates are: S 22 $39^{\prime} 30^{\prime \prime}-22^{\circ} 46^{\prime} 50^{\prime \prime}$ latitude and W 42 $57^{\prime} 00^{\prime \prime}$ $43^{\circ} 06^{\prime} 40^{\prime \prime}$ longitude, in Rio de Janeiro State of Brazil. The total area is $138.25 \mathrm{~km}^{2}$, of which $61.80 \mathrm{~km}^{2}$ correspond to mangrove swamps that occupying the coastline of the municipalities cited. The photographic records were done with a digital camera with 10x zoom every 15 minutes when the birds were eating and visual observations were done using binocular all time by a second observer. All activities were carried out within the limits of Itambi district, every two weeks for three hours over a one-year period. The records and observations occurred only at times when the birds were feeding. The bunches of palm oil were 12 meters high and photographic records occurred between 10 and 15 meters away from the tree.

\section{Results}

Over a one year period with a sampling effort of 72 hours 78 observations of birds of the species Cathartes burrovianus Cassin, 1845 (Cathartidae) were made and photographed feeding on fruits of the oleaginous plant Elaeis guineensis Jacq. 1897 (Arecaceae) (Figures 1A and 1B). The behavior of these birds was observed and recorded during each meal: a single individual fed on a bunch of the fruits of the African oil palm (E. guineensis), while the others awaited their turn to feed; only the flesh of the fruit was consumed, while the seed was usually discarded, however some animals were seen carrying the whole fruit away; the morning was the preferred time to feed on these oil palm fruits. Only mature fruits that were still attached to the bunch were consumed. Vultures were not seen eating any fruits on the ground throughout the observation periods.
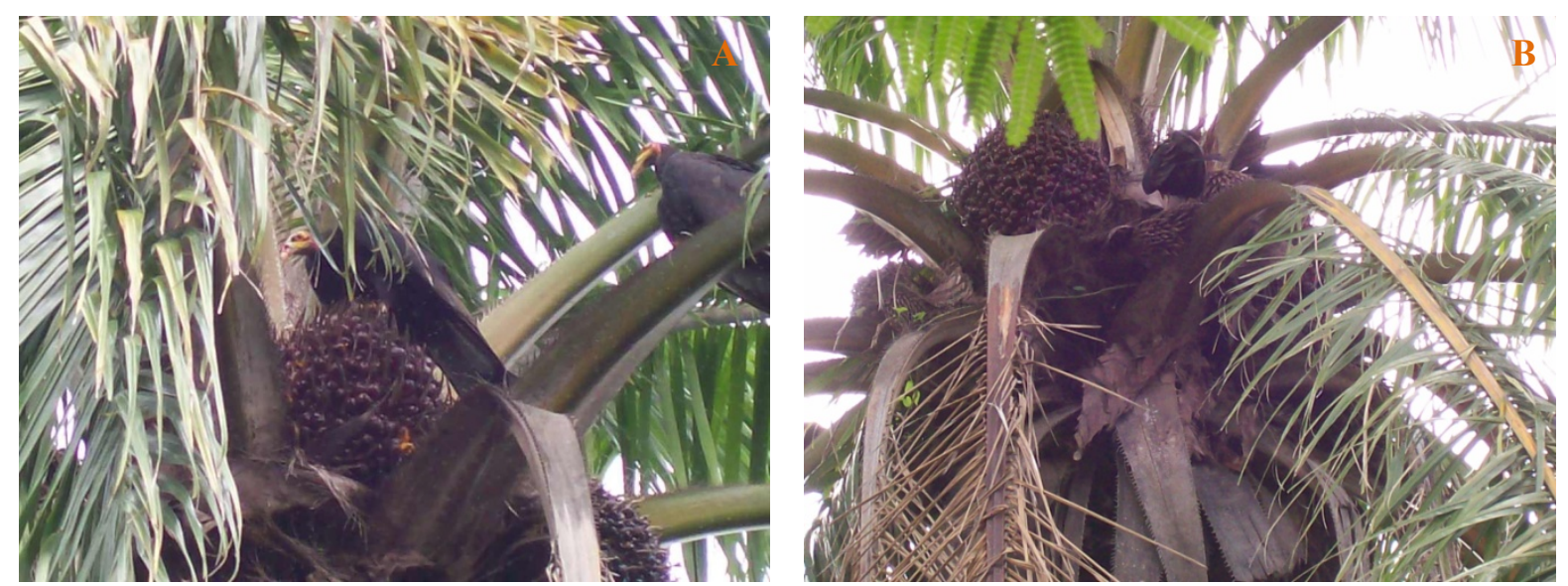

Figure 1. A) Photo of two individuals of the species Lesser Yellow-headed Vulture (C. burrovianus), while one feeds the other watches. B) An individual of the species Lesser Yellow-headed Vulture (C. burrovianus) feeding on a bunch of E. guineensis fruits

\section{Discussion}

The mangrove swamp in the Guapi-Mirim Environmental Protection Area is a protected area, rich in biodiversity of crustaceans, birds, reptiles, fish, insects and mammals. Due to its considerable size there is an abundance of prey for any predator and detritivorous animals find an abundance of food resources. In this environmentally protected area, three species of vultures are commonly found: C. aura (Turkey Vulture), C. atratus (Black Vulture) and C. burrovianus (Lesser Yellow-headed Vulture). According to some authors, these three species feed primarily on animal carcasses (Mota Júnior, 1990; Telino-Júnior et al., 2005).

The carrion birds have an important ecological function: they consume dead animals and thus hinder the spread of pathogenic bacteria. Their importance as a predator is also notable, along with other predators, in controlling the populations of their preys. 
Surrounding the Guapi-Mirim Environmental Protection Area, there are a large number of farms that are focused on subsistence farming. Some of these properties slaughter their animals for their own consumption or commercialization, and the ensuing organic wastes are consumed by vultures, or are taken to the mangrove swamp, and consumed by many other animals as well.

The species $C$. aura, which is also a scavenger species, and has been seen feeding on the fruits of the African oil palm E. guineensis (Pinto, 1965). This oil palm is well known throughout Brazil, because its fruits and fruit oil are greatly appreciated in the Brazilian culinary. The fruits of this oil palm attract many animals, including insects or even some species of insectivorous birds that according to Koh (2008) help defend oil palms from the attack of these insects. However, Pinto (1965) only described that $C$. aura ate the fruits of E. guineensis on the ground and did not discuss whether other species of vultures might have similar behavior. Other behavior during meals, such as the frequency of visiting these oil palm trees during the year, or even the social behavior during meals were not reported by Pinto (1965) either; thus only providing a casual overview of the feeding habits of $C$. aura.

The species $C$. atratus does not present a very different behavior from other species, because it also feeds on carcasses, young turtles or birds (Antas, 2005; Sick, 1997). C. atratus has also been described as a very opportunistic species, feeding on food waste in the big cities (Ferguson-less \& Christies, 2001; Antas, 2005). However, no references have been found of $C$. atratus feeding on the fruit of the oil palm E. guineensis or any other type of fruit in Brazil. In the Guapi-Mirim Environmental Protection Area this species is usually seen feeding on small animals such as crustaceans or fish.

The species $C$. burrovianus is frequently seen within the mangrove swamps, as well as in the surrounding areas, feeding on dead animals. The feeding behavior of these vultures has also been documented by various authors, who have also highlighted that these animals can feed on insects, amphibians, snakes and birds (Sigrist, 2006; Silveira \& Belmonte, 2005; Almeida et al., 2010). C. burrovianus do not appear to have a specific preference, as they have been observed feeding on carcasses of many different animals such as: anteaters, crab-eating foxes, nutrias, coatis, capybaras, lizards and eels (Wetmore, 1965; Di Giacomo, 2005). This shows that this species is quite eclectic. Stiles and Skutch (1989) described this species as an excellent hunter, and is able to catch fish in its claws. When the tides rise in the Guapi-Mirim Environmental Protection Area some fish species accompany the rising tide and become prey for predators. This is a very important moment for raptors such as $C$. burrovianus, to prey on these 'prey fish' despite the fact that they can find a great abundance of food in this environmentally protected area such as crabs, snakes, skunks as well as many other birds that can serve as food for this species of vulture.

The species C. burrovianus has a wide geographical distribution, and can be found from Mexico to Argentina, including Brazil (Sick, 1997). This species has been reported as an excellent hunter and even their sense of smell has been described (Sick, 1997). According to Sick (1997), due to its excellent sense of smell C. burrovianus finds decaying carcasses before other species. Migratory movements of this species have been reported by Bildstein (2006) and the fluctuation of their population has also been observed in several countries, especially seasonal population variations (Friedmann \& Smith, 1950; Monroe, 1968; Clinton-Eitniear, 1985; Binford, 1989; Ridgely \& Gwynne, 1989; Hilty, 2003). Although all these authors emphasized the migratory capacity $C$. burrovianus, they did not comment on the habit of this species feeding on fruits, only highlighting its ability as a scavenger or predator.

Of the three species mentioned above as common inhabitants in the Guapi-Mirim Environmental Protection Area, only the species C. burrovianus has been observed feeding on the fruits of the oil palm E. guineensis. C. aura or $C$. atratus were not observed feeding on the fruits of E. guineensis.

The eating habits of birds have been shown to be quite varied; they may consume seeds, fruits, live animals and/or animal carcasses. The habits of 225 bird species were investigated at the Gurjaú State Reserve, Pernambuco, Brazil, and in the southerly forest zone of the reserve C. burrovianus was recorded as an exclusively detritivorous species (Telino-Júnior et al., 2005) but with no fruit feeding habits.

The consumption of the fruits of E. guineensis by the species $C$. burrovianus has not been fully elucidated; however some recent studies emphasize the importance of this fruit for digestibility. The addition of byproducts of $E$. guineensis to the daily ration of livestock can help fatten these animals. The use of these products was recently introduced into Brazil, and these livestock showed an improved digestibility (Silva et al., 2005); therefore C. burrovianus appear to be consuming these fruits to complement their diet and improve their digestion.

The observation of $C$. burrovianus feeding on the oil palm E. guineensis fruits daily reveals a lack of knowledge 
of the habits of this species, making us believe that these fruits represent part of its complementary diet. Other predator species have also been observed feeding on this fruit in Para, Brazil, for example the Swallow-tailed Kite, Elanoides forficatus (Linnaeus, 1758), (Olmos et al., 2006). This fact again reinforces the fact that the fruits of this plant have some kind of importance for the digestive tract of predators or carrion birds.

Besides the use of the fruits for feeding, another very particular behavior of $C$. burrovianus was also observed. These vultures feed in small groups with a maximum of 3 individuals; however each animal feeds individually only on one bunch of E. guineensis fruits, while the others wait their turn to eat. Some animals carry the fruit away with them, possibly to feed young that are still in the nest. This fact may demonstrate another ecological importance of this species, as a seed spreader. The fact that they are always seen alone or in a group of three at a maximum reveals few social habits.

\section{Conclusion}

Considering that the Guapi-Mirim Environmental Protection Area presents a rich variety and a wide availability of food resources throughout the year, we conclude, after twelve months of observations and photographs that the species $C$. burrovianus uses the fruit of the oil palm E. guineensis not only as an alternative food in the absence of carcasses, but also a complement to their daily dietary needs. This fact may really be related to the higher digestibility of carrion or animals preyed upon by these birds.

\section{Acknowledgements}

The authors would like to thank David Graham Straker for the English revision, Prefeitura Municipal de Itaboraí and Escola Municipal José Ferreira for financial support and to the Instituto Chico Mendes de Conservação da Biodiversidade (ICMBio-IBAMA) that gave permission for the use of the images.

\section{References}

Almeida, T. O., Machado, F. C., \& Costa, H. C. (2010). Exchanging carrion for fresh meat: the vulture Cathartes burrovianus (Aves, Cathartidae) preys on the snake Xenodon merremii (Serpentes, Dipsadidae) in southeastern Brazil. Biotemas, 23(4), 177-180. http://dx.doi.org/10.5007/2175-7925.2010v23n4p177

Antas, P. T. Z. (2005). Aves do pantanal. SESC. Retrieved from http://www. avespantanal.com.br

Bakoumé, C., Shahbudin, N., Yacob, S., Siang, C. S., \& Thambi, M. N. A. (2013). Improved Method for Estimating Soil Moisture Deficit in Oil Palm (Elaeis guineensis Jacq.) Areas With Limited Climatic Data. Journal of Agricultural Science, 5(8), 57-65. http://dx.doi.org/10.5539/jas.v5n8p57

Bildstein, K. L. (2006). Migrating raptors of the world: Their ecology and conservation (1st ed.). Cornell University Press, Ithaca, New York, USA.

Binford, L. C. (1989). A distributional survey of the birds of the Mexican state of Oaxaca. Ornithological Monographs, 43, 1-418.

Brown, L., \& Amadon, D. (1968). Eagles, Hawks and Falcons of the world (1st ed.). New Jersey, USA: The Well fleet Press.

Clinton-Eitniear, J. (1985). Notes on the relative abundance and distribution of the Lesser Yellow-headed Vulture in Mexico and Belize, Central America. Bulletin. World Working Group Birds of Prey, 2, 17-22.

Di Giacomo, A. G. (2005). Aves de la Reserva El Bagual. Historia natural y paisaje de la Reserva El Bagual, Provincia de Formosa, Argentina. Inventario de la fauna de vertebrados y de la flora vascular de un área protegida del Chaco Húmedo. Temas de Naturaleza y Conservación-Monografia de Aves Argentinas (4th ed).

Di Giacomo, A. G., \& Krapovickas, S. F. (n.d.). Aves Argentinas, Buenos Aires: Asociación Ornitológica del Plata. Retrieved from http://www.avesargentinas.org.ar/12/03-reserva_el_bagual.php

Ferguson-Lees, J., \& Christie, D. A. (2001). Raptors of the world (1st ed). New York: Houghton Miffl in Company.

Friedmann, H., \& Smith, F. D. (1950). A contribution to the ornithology of northeastern Venezuela. Procedure United State Natural Museum, 100, 411-538. http://dx.doi.org/10.5479/si.00963801.100-3268.411

Hilty, S. L. (2003). Birds of Venezuela (2nd ed). New Jersey, Princeton: Princeton Univ. Press.

Houston, D. C. (1994). Family Cathartidae. In J. del Hoyo, A. Elliott, \& J. Sargatal (Eds.), Handbook of the birds of the world. Barcelona: Lynx Editions.

Koh, L. P. (2008). Birds defend oil palms from herbivorous insects. Ecological Applications, 18, 821-825. http://dx.doi.org/10.1890/07-1650.1 
Monroe, B. L. Jr. (1968). A distributional survey of the birds of Honduras. American Ornithologists' Union Monograph, 7. http://dx.doi.org/10.2307/40168043

Mota Júnior, J. C. (1990). Estrutura trófica e composição das avifaunas de três hábitats terrestres na região central do estado de São Paulo. Revista Brasileira de Ornitologia, 1, 65-71.

Olmos, F., Pacheco, J. F., \& Silveira, L. F. (2006). Notas sobre aves de rapina (Cathartidae, Acciptridae e Falconidae) brasileiras. Revista Brasileira de Ornitologia, 14(4), 401-404.

Pinto, O. M. O. (1965). Dos frutos da palmeira Elaeis guineensis na dieta de Cathartes aura ruficollis. Hornero, 8 , 276-277.

Ridgely, R. S., \& Gwynne, J. A. JR. (1989). Birds of Panama with Costa Rica, Nicaragua, and Honduras (2nd ed.). Princeton, New Jersey: Princeton University Press.

Sick, H. (1997). Ornitologia Brasileira (1st ed.). Riode Janeiro: Editora Nova Fronteira.

Sigrist, T. (2006). Aves do Brasil: Uma visão artística (2nd ed.). São Paulo: Avis Brasilis Editora.

Silva, H. G. O., Pires, A. J. V., Silva, F. F., Veloso, C. M., Carvalho, G. G. P., Cezário, A. S., \& Santos, C. C. (2005). Digestibilidade aparente de dietas contendo farelo de cacau ou torta de dendê em cabras lactantes. Pesquisa Agropecuária $\quad$ Brasileira, $\quad$ Brasília, $405-411$. http://dx.doi.org/10.1590/S0100-204X2005000400013

Silveira, L. F., \& Belmonte, F. J. (2005). Comportamento reprodutivo e hábitos da ararajuba, Guarouba guarouba, no município de Tailândia, Pará. Revista Brasileira de Ornitologia, 13(1), 89-93.

Stiles, F. G., \& Skutch, A. F. (1989). A Guide to the Birds of Costa Rica (1st ed.). Ithaca, NY: Cornell University Press.

Telino-Júnior, W. R., Dias, M. M., Azevedo Júnior, S. M., Lyra-Neves, R. M., \& Larrazábal, M. E. L. (2005). Estrutura trófica da avifauna na Reserva Estadual de Gurjaú, Zona da mata Sul, Pernambuco, Brasil. Revista Brasileira de Zoologia, 22(4), 962-973. http://dx.doi.org/10.1590/S0101-81752005000400024

Wetmore, A. (1965). The birds of the Republic of Panama. Part 1. Tinamidae (Tinamous) to Rhynchopidae (Skimmers). Smithsonian Miscellaneous Collections, 150(1), 1-483.

Wink, M. (1995). Phylogeny of Old and New World vultures (Aves: Accipitridae and Cathartidae) inferred from nucleotide sequences of the mitochondrial cytochrome b gene. Zeitschrift der Naturforschenden (Abteilung C), $50,868-882$.

\section{Copyrights}

Copyright for this article is retained by the author(s), with first publication rights granted to the journal.

This is an open-access article distributed under the terms and conditions of the Creative Commons Attribution license (http://creativecommons.org/licenses/by/3.0/). 